\title{
Effect of goat milk composition on cheesemaking traits and daily cheese production
}

\author{
Michele Pazzola, ${ }^{1}$ Giorgia Stocco, ${ }^{1 *}$ Maria L. Dettori, ${ }^{1}$ Giovanni Bittante, ${ }^{2}$ and Giuseppe M. Vacca ${ }^{1}$ \\ ${ }^{1}$ Department of Veterinary Medicine, University of Sassari, via Vienna 2, 07100 Sassari, Italy \\ ${ }^{2}$ Department of Agronomy, Food, Natural resources, Animals and Environment (DAFNAE) University of Padova, viale dell'Università 16, \\ 35020 Legnaro (PD), Italy
}

\section{ABSTRACT}

Cheese yield is strongly influenced by the composition of milk, especially fat and protein contents, and by the efficiency of the recovery of each milk component in the curd. The real effect of milk composition on cheesemaking ability of goat milk is still unknown. The aims of this study were to quantify the effects of milk composition; namely, fat, protein, and casein contents, on milk nutrient recovery in the curd, cheese yield, and average daily yield. Individual milk samples were collected from 560 goats of 6 different breeds. Each sample was analyzed in duplicate using the 9-laboratory milk cheesemaking assessment, a laboratory method that mimicked cheesemaking procedures, with milk heating, rennet addition, coagulation, curd cutting, and draining. Data were submitted to statistical analysis; results showed that the increase of milk fat content was associated with a large improvement of cheese yield because of the higher recovery of all milk nutrients in the curd, and thus a higher individual daily cheese yield. The increase of milk protein content affected the recovery of fat, total solids, and energy in the curd. Casein number, calculated as casein-to-protein ratio, did not affect protein recovery but strongly influenced the recovery of fat, showing a curvilinear pattern and the most favorable data for the intermediate values of casein number. In conclusion, increased fat and protein contents in the milk had an effect on cheese yield not only for the greater quantity of nutrients available but also for the improved efficiency of the recovery in the curd of all nutrients. These results are useful to improve knowledge on cheesemaking processes in the caprine dairy industry.

Key words: fat recovery, protein recovery, caprine cheese, casein number, cheese yield

Received July 17, 2018.

Accepted January 13, 2019.

*Corresponding author: giorgiastocco12@gmail.com

\section{INTRODUCTION}

The main use of goat milk is cheesemaking (Boyazoglu and Morand-Fehr, 2001), and both cheese yield $(\% \mathbf{C Y})$ and daily cheese yield $(\mathbf{d C Y})$ are the final economic target of many dairy goat farmers. In particular, the assessment or prediction of $\% \mathrm{CY}$ and $\mathrm{dCY}$ of individual goats is an important topic in studies regarding the existence of a genetic basis for those traits (Othmane et al., 2002) and in crossbreeding programs. It is recognized that the breed has a large effect on bovine \%CY traits (Verdier-Metz et al., 1995). In goat, \%CY shows a large variability according to the breed and the individual animal (Vacca et al., 2018a); however, the large \% CY variability among breeds and animals within the same breed is also attributable to the differences in milk yield and composition, mainly to fat and protein contents (Banks and Tamime, 1987; Kalantzopoulos, 1993; Verdier-Metz et al., 2001). In addition, the recovery of each milk component in the curd (\%REC; Stocco et al., 2018a) is an important aspect to achieve overall efficiency of cheesemaking. Milk fat and protein contents are considered in formulas to predict cheese yield (Emmons and Modler, 2010). Those formulas often assume a constant \%REC of fat and protein, because the predicted $\% \mathrm{CY}$ is proportional to the amount of fat and protein available, and do not take into account the complex relationships between milk composition and cheesemaking efficiency.

In a study by Vacca et al. (2018a), the overall effect of breed on cheesemaking traits was split into direct effects of breed (independent from milk yield and composition) and indirect effects of breed (mediated by milk yield and composition). Those results show that a large proportion of the total breed variance is attributable to milk yield and composition, and prove that a deeper investigation about the real effect of milk composition on cheesemaking ability of goat milk is needed.

During recent decades, the replacement of local goat breeds with specialized breeds has led to an increase in total milk yield and a decrease in milk fat and protein contents and coagulation ability (Boyazoglu and Mo- 
rand-Fehr, 2001). Large differences have been observed among goat breeds in terms of milk composition (Sung et al., 1999; Goetsch et al., 2011; Lôbo et al., 2017), coagulation ability (Clark and Sherbon, 2000; Pazzola et al., 2018; Vacca et al., 2018b), and cheesemaking efficiency (Soryal et al., 2005). Milk composition significantly influences yield and sensory quality of cheese, and results from the literature regarding dairy cows cannot be adapted to goats. Large differences exist among species with regard to coagulation properties, curd firming and syneresis (Bittante et al., 2012), and, as a consequence, recovery of milk nutrients in the curd and cheese yield. Hence, it is important for goat farmers and the caprine cheese industry to understand the effect of milk components, in particular fat and protein, on cheesemaking ability. The available literature is mainly focused on the effect of milk composition on measured fresh cheese (Guo et al., 2004) or predicted fresh cheese (Zeng et al., 2007). Investigations of the effects of milk traits on TS and moisture retained in cheese, the efficiency of recovery of milk nutrients in the curd, and the average daily production of cheese per goat are still lacking.

For these reasons, the present research was carried out to quantify the effect of milk fat, protein, and casein number, calculated as casein-to-protein ratio, on (1) recovery of milk nutrients in the curd, (2) measured cheese yields, and (3) daily cheese yields per goat.

\section{MATERIALS AND METHODS}

\section{Milk Sampling and Analyses}

Five hundred and sixty goats belonging to 6 different breeds (Saanen, Camosciata delle Alpi, MurcianoGranadina, Maltese, Sarda, and Sarda Primitiva) and reared in 35 farms distributed over the whole island of Sardinia (Italy) were sampled. All goats were milked twice a day in the morning (at about $0600 \mathrm{~h}$ ) and afternoon (at about $1700 \mathrm{~h}$ ). For the present study, goats were sampled once (1 sampling day for each farm) during afternoon milking for milk composition and cheesemaking analyses. This study is a part of a larger project on the comparison of milk and cheesemaking traits from the 6 goat breeds, which also describes farm characteristics (Vacca et al., 2018a). Briefly, farms were classified on the basis of type of management and flock size. Three management types were considered: traditional (extensive system with free grazing of natural pastures, seasonal milk production, family operated); intermediate (semi-extensive system, cultivated grasslands, and control of estrus and kidding season); and modern (semi-intensive system, housing in modern buildings and use of modern facilities, common use of TMR, out-of-season kidding and continuous milk production, operated by hired workers, consultancy of experts in animal feeding). With regard to flock size, farms were classified as small ( $<100$ producing goats), medium-sized (100-200), and large ( $>200)$. With regard to breed, Saanen goats $(\mathrm{n}=99)$ were characterized by parity at $3.3 \pm 1.7$ (means \pm SD) and DIM at $109 \pm 72$; Camosciata delle Alpi goats $(\mathrm{n}=98)$ were characterized by parity and DIM very close to the Saanen breed $(3.1 \pm 2.0$, and $78 \pm 37$, respectively); parity and DIM of the Murciano-Granadina goats $(\mathrm{n}=89)$ were similar to Saanen and Camosciata delle Alpi, at $3.0 \pm 1.4$ and $129 \pm 38$ DIM; Maltese goats $(\mathrm{n}=104)$ were characterized by parity at $3.8 \pm 1.7$, and DIM at $129 \pm 49$; and the Sarda $(\mathrm{n}=86)$ and Sarda Primitiva $(\mathrm{n}=84)$, local breeds from the island of Sardinia (Italy), had parity at $4.7 \pm 2.0$ and $5.1 \pm 2.5$, and DIM at $129 \pm 36$ and 124 \pm 40 DIM, respectively.

Milk fat and protein were analyzed using a MilkoScan FT6000 milk analyzer (Foss Electric A/S, Hillerød, Denmark), calibrated according to FIL-IDF recommendations (ISO 9622:2013; ISO-IDF, 2013). Casein number was calculated as the casein-to-protein ratio and multiplied by 100 . Daily milk yield (kg/d) was calculated as the sum of morning plus afternoon milking yields.

\section{Individual Cheesemaking Procedure}

The laboratory milk cheesemaking assessment (9-MilCA) procedure proposed by Cipolat-Gotet et al. (2016) was used to measure individual \% $\mathrm{CY}$ and \% REC traits. The laboratory cheesemaking assessment procedure was performed with 2 replicates per each animal (2 aliquots of $9 \mathrm{~mL}$ of the same milk sample), for a total of 1,120 observations. Each milk replicate was poured into a glass tube and inserted into the modified rack of the lactodynamograph instrument (Formagraph, Foss Italia S.P.A., Padova, Italy). Samples were heated to $35^{\circ} \mathrm{C}$ for $15 \mathrm{~min}$ and mixed with $0.2 \mathrm{~mL}$ of a rennet solution [Hansen Standard 215 (Pacovis Amrein AG, Bern, Switzerland), $80 \pm 5 \%$ chymosin and $20 \pm 5 \%$ pepsin; diluted to $1.2 \%$ (wt/vol) in distilled water; 0.0513 international milk clotting units/mL of milk]. The sample rack was transferred to the lactodynamograph for a 30 -min test at $35^{\circ} \mathrm{C}$. At the end of the analysis, coagulated milk samples were manually cut and moved to a heater at $55^{\circ} \mathrm{C}$ for the curd-cooking phase, which lasted $30 \mathrm{~min}$. Fifteen minutes after the beginning of the cooking phase, each sample was subjected to a further manual cutting by the same operator. At the end of the cooking phase, each glass tube was removed from the sample rack and the curd was separated from the whey. Separation was performed at 
room temperature using a conical funnel containing a concave metallic net. The curd was gently pressed on the net by using a stainless steel spatula and drained on the net for $15 \mathrm{~min}$. Whey was collected in the underlying plastic tube. The obtained curd and whey were weighed using a precision scale. Whey composition was assessed by using an infrared spectrophotometer (MilkoScan FT2, Foss Electric). The composition of the curd was calculated by subtracting the weight of the nutrient in the whey from the weight of the corresponding nutrient in the processed milk. The \%CY traits were $\% \mathrm{CY}_{\mathrm{CURD}}, \% \mathrm{CY}_{\text {SOLIDS }}$, and $\% \mathrm{CY}_{\text {WATER }}$, calculated as the ratio of the weight $(\mathrm{g})$ of fresh curd, curd DM, and water retained in curd, respectively, to the weight of the processed milk (g), and multiplied by 100 . Daily cheese yields $\left(\mathrm{dCY}_{\mathrm{CURD}}, \mathrm{dCY}_{\text {SOLIDS }}\right.$, and $\mathrm{dCY}_{\text {WATER }} ; \mathrm{kg} / \mathrm{d}$ ) were calculated by multiplying the $\% \mathrm{CY}\left(\% \mathrm{CY}_{\mathrm{CURD}}, \% \mathrm{CY}\right.$ SOLIDS, and $\% \mathrm{CY}_{\text {WATER }}$, respectively) by the daily milk yield of the individual animal. The $\%$ REC traits were $\% \mathrm{REC}_{\text {PROTEIN }}, \% \mathrm{REC}_{\mathrm{FAT}}$, and $\% \mathrm{REC}_{\text {SOLIDS }}$, calculated as the ratio of the weight $(\mathrm{g})$ of the curd components (protein, fat, and DM, respectively) to the same component of processed milk (g) and multiplied by 100. Recovery of energy in the curd $\left(\% \mathrm{REC}_{\text {ENERGY }}\right)$ was calculated by estimating energy of milk and curd using an equation proposed by the NRC (2001), converted to megajoules per kilogram, and multiplied by 100 .

\section{Statistical Analysis}

Data were analyzed using a MIXED procedure (version 9.4, SAS Institute Inc., Cary, NC), according to the model

$$
\begin{gathered}
\mathrm{Y}_{\text {efghijklmn }}=\mu+\text { DIM }_{\mathrm{e}}+\text { Parity }_{\mathrm{f}}+\text { Fat }_{\mathrm{g}}+\text { Protein }_{\mathrm{h}} \\
+ \text { Casein }_{\text {number }}+\text { Farm }_{\mathrm{j}}+\text { Breed }_{\mathrm{k}}+\text { Animal }_{1} \\
+{\text { Glass } \text { Tube }_{\mathrm{m}}}+\mathrm{e}_{\text {efghijklmn }}
\end{gathered}
$$

where $Y_{\text {efghijklmn }}$ is the observed trait; $\mu$ is the overall intercept of the model; $\mathrm{DIM}_{\mathrm{e}}$ is the fixed effect of the eth class of DIM [e = 1-4; class 1: $<80$ d (146 goats); class 2: 81-120 d (157 goats); class 3: 121-160 d (157 goats); class 4: $>160 \mathrm{~d}$ (100 goats)]; Parity $\mathrm{f}_{\mathrm{f}}$ is the fixed effect of the fth parity $[\mathrm{f}=1-3$; class 1 : parity 1 and 2 (193 goats); class 2: parity 3 and 4 (205 goats); class 3 : parity $\geq 5$ (162 goats)]; Fat is $_{\text {in }}$ the fixed effect of the gth class of fat percentage $(\mathrm{g}=1-7$; class $1:<2.77$; class 2 : 2.77-3.48; class 3: 3.49-4.21; class 4: 4.22-4.95; class 5: 4.96-5.68; class 6: 5.69-6.41; class 7: $>6.41$ ); Protein $_{\mathrm{h}}$ is the fixed effect of the hth class of protein percentage (h $=1-7$; class $1:<2.91$; class 2 : 2.91-3.17; class 3 : $3.18-$
3.44; class 4: 3.45-3.72; class 5: 3.73-4.00; class 6: 4.01-4.27; class 7: $>4.27$ ); Casein number ${ }_{i}$ is the fixed effect of the ith class of percentage casein number $(\mathrm{i}=$ $1-7$; class 1 : $<74.0$; class 2 : $74.0-75.6$; class 3 : 75.7-77.3; class 4: 77.4-79.1; class 5: 79.2-80.8; class $6: 80.9-82.5$; class 7: >82.5); Farm $_{\mathrm{j}}$ is the random effect of the jth farm $(\mathrm{j}=1-35)$; Breed $_{\mathrm{k}}$ is the random effect of the kth breed ( $\mathrm{k}=$ Saanen, Camosciata delle Alpi, MurcianoGranadina, Maltese, Sarda, and Sarda Primitiva); Ani$\mathrm{mal}_{1}$ is the random effect of the lth animal $(1=1-1,120$ observations, 2 replicates for each of the 560 goats); Glass Tube $_{m}$ is the fixed effect of the mth glass tube of the modified Formagraph instrument $(\mathrm{m}=1$ to 8$)$; and $\mathrm{e}_{\text {efghijklmn }}$ is the random residual $\sim N\left(0, \sigma_{e}^{2}\right)$, where $\sigma_{e}^{2}$ is the residual variance. Each of the 7 classes of fat, protein, and casein number was designed on the basis of distribution of the variables: each single class explained 0.5 standard deviations of the variable; the fourth was centered on the mean value and the first and the seventh represented the tails of the distribution. The division into classes was planned both to describe possible nonlinearity of the relationships of fat, protein, and casein number and to collect a sufficient number of observations in each class. All the fixed effects included in the model were tested using the variance of the animal as the error line. Casein content was not included in the model to avoid multicollinearity with protein content. In an exploratory analysis, daily milk yield was included in the model described above; because it was significant only for daily cheese productions, it was not considered in model [1].

Orthogonal polynomial contrasts (linear, quadratic, and cubic pattern) were estimated between least squares means of classes of fat, protein, and casein number. Pearson product-moment correlations were assessed between milk composition and cheesemaking traits.

\section{RESULTS AND DISCUSSION}

The effects of farm, breed, parity, and DIM were presented and discussed in detail in a previous paper (Vacca et al., 2018a), and results are only summarized in this section.

\section{ANOVA}

Descriptive statistics (mean and SD) of milk fat, protein, and casein number are reported in Table 1, together with Pearson product-moment correlation between these milk traits and \% REC, \%CY, and dCY.

The effects of the different milk traits affecting cheesemaking efficiency are often similar because those traits, mainly fat and protein, are correlated with each 
Table 1. Descriptive statistics (mean and SD) and Pearson product-moment correlations between individual milk fat, protein, and casein numbers and nutrient recovery, cheese yield, and daily yield traits of goat milk samples

\begin{tabular}{|c|c|c|c|c|c|}
\hline Item & Mean & $\mathrm{SD}$ & Fat, $\%$ & Protein, $\%$ & $\begin{array}{c}\text { Casein } \\
\text { number, }\end{array}$ \\
\hline Mean & & & 4.61 & 3.64 & 78 \\
\hline SD & & & 1.47 & 0.60 & 2.95 \\
\hline \multicolumn{6}{|c|}{ Nutrient recovery, \% } \\
\hline Fat & 80.86 & 5.84 & $0.38^{* * *}$ & $0.46^{* * *}$ & $0.33^{* * *}$ \\
\hline Protein & 81.63 & 2.51 & $0.33^{* * *}$ & $0.16^{* * *}$ & $0.13^{*}$ \\
\hline DM & 55.75 & 5.54 & $0.81^{* * *}$ & $0.69^{* * *}$ & $0.44^{* * *}$ \\
\hline Energy & 66.40 & 5.49 & $0.74^{* * *}$ & $0.63^{* * *}$ & $0.45^{* * *}$ \\
\hline \multicolumn{6}{|c|}{ Cheese yield, $\%$} \\
\hline Curd & 15.73 & 2.83 & $0.76^{\text {*** }}$ & $0.60^{* * *}$ & $0.46^{* * *}$ \\
\hline DM & 7.74 & 1.76 & 0.50 *** & $0.78^{* * *}$ & $0.60^{* * *}$ \\
\hline Water & 7.97 & 1.49 & $0.39^{* * *}$ & $0.35^{* * *}$ & $0.22^{* * *}$ \\
\hline \multicolumn{6}{|c|}{ Daily yield, ${ }^{2} \mathrm{~kg} / \mathrm{d}$} \\
\hline Curd & 0.29 & 0.15 & $-0.27^{* * *}$ & $-0.40^{* * *}$ & $-0.30^{* * *}$ \\
\hline DM & 0.14 & 0.07 & $-0.17^{* * *}$ & $-0.32^{* * *}$ & $-0.23^{* * *}$ \\
\hline Water & 0.15 & 0.08 & $-0.35^{* * *}$ & $-0.45^{* * *}$ & $-0.34^{* * *}$ \\
\hline
\end{tabular}

${ }^{1}$ Casein number $=$ casein to protein ratio, multiplied by 100 .

${ }^{2}$ Obtained by multiplying the cheese yield of curd, DM, and water by the daily milk yield of the individual animal.

${ }^{*} P<0.05 ; * * * P<0.001$.

other. In our study, the concurrent effects of all the major sources of variation (i.e., herds, breeds, parity, lactation stage, and milk composition) were included in the model to obtain a clearer picture of individual factors affecting cheesemaking efficiency. The ANOVA for $\%$ REC, $\% \mathrm{CY}$, and daily yield traits are summarized in Table 2. Among the random effects, the individual animal was the main factor explaining the variability for \%REC (from 66-80\%) and \%CY traits (from
$42.2-74.8 \%$ ), whereas farm (from $37.7-40.5 \%$ ) was the factor with the most important effect on dCY traits.

\section{Contribution of Fat}

High concentrations of milk fat (Table 3) were associated with higher recovery of nutrients in the curd $(3.1,3.8,13.4$, and $12.4 \%$ from the lowest to the highest class, respectively, for $\% \mathrm{REC}_{\mathrm{FAT}}, \% \mathrm{REC}_{\mathrm{PROTEIN}}$,

Table 2. The ANOVA for nutrients recovery, cheese yields, and daily yield traits of milk samples from individual goats $(\mathrm{n}=1,120)$ of 6 breeds, with $F$-value and significance for fixed effects and the proportion of variance (in percentage) explained by random effects

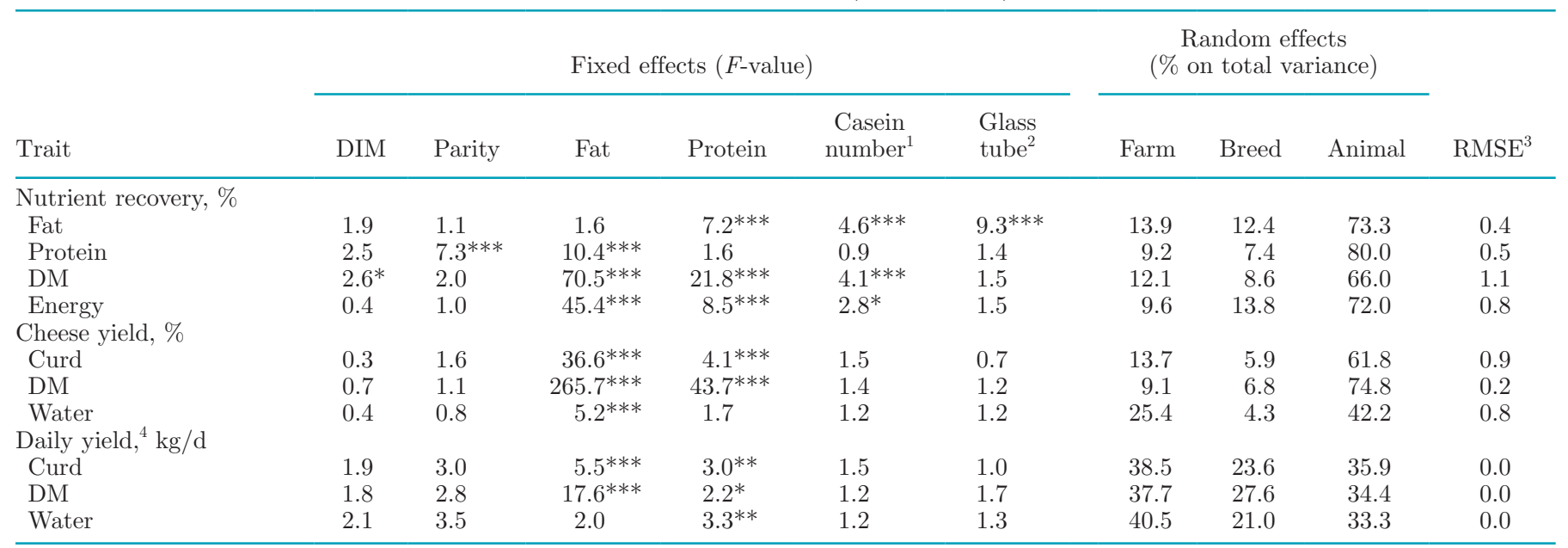

${ }^{1}$ Casein number $=$ casein to protein ratio, multiplied by 100 .

${ }^{2}$ Glass tube of the modified Formagraph instrument.

${ }^{3} \mathrm{RMSE}=$ root means square error.

${ }^{4}$ Obtained by multiplying the cheese yield of curd, DM, and water by the daily milk yield of the individual animal.

${ }^{*} P<0.05 ;{ }^{* *} P<0.01 ;{ }^{* * *} P<0.001$. 
\% $\mathrm{REC}_{\mathrm{SOLIDS}}$, and $\% \mathrm{REC}_{\text {ENERGY }}$; data not shown in tables), higher \% $\mathrm{CY}$ traits $(6.5,4.5$, and $1.6 \%$, respectively, for $\% \mathrm{CY}_{\mathrm{CURD}}, \% \mathrm{CY}_{\text {SOLIDS }}$, and $\% \mathrm{CY}_{\text {WATER }}$; data not shown in tables), and higher $\mathrm{dCY}$ traits $(0.12,0.07$, and $0.03 \mathrm{~kg} / \mathrm{d}$, respectively, for $\mathrm{dCY}_{\mathrm{CURD}}, \mathrm{dCY} \mathrm{Y}_{\text {SOLIDS }}$, and $\mathrm{dCY}$ WATER; data not shown in tables). As expected, milk fat content was related to $\% \mathrm{CY}_{\mathrm{CURD}}$. Indeed, fat is one of the main components of cheese and it is included in all formulas predicting cheese yield (Emmons and Modler, 2010). However, formulas to predict \%CY, which are useful for bovine milk, are generally based on the linear relationships between milk composition and cheese yield. However, those formulas do not take into account the specificity of goat milk coagulation, curd firming and syneresis processes, interactions, and the possible nonlinearity of relationships among milk traits.

In a study on the relationship between $\% \mathrm{CY}$ and goat milk composition, Guo et al. (2004) reported a strong relationship $(\mathrm{r}=0.75)$ between the 2 traits and suggested that fat content could be used as a reliable predictor of \%CY of Chevre fresh cheese. In addition, Zeng et al. (2007) found similar results $(r=0.81)$ in fresh goat cheese, but not in semihard and hard cheeses.

Results from Table 3 show that the positive effect of milk fat content on cheese yield also depended on the linear improvement of the fat recovery rate in the curd. No study on the effects of milk nutrient contents on their recovery rate in the curd and on related cheesemaking traits is available in the literature for goat milk. The explanation of this effect was attributable to milk coagulation and curd-firming processes. A previous paper by Stocco et al. (2018b), on the effect of milk fat, protein, and casein contents on coagulation ability of goat milk, showed that milk samples with high content of fat are characterized by better coagulation traits; namely, shorter coagulation time, higher curd-firming rate, and earlier attainment of maximum firmness of the curd.

More information is available on dairy cattle than on goats. In Cheddar cheese, Fenelon and Guinee (1999) found that the recovery of fat increased significantly from 80.84 to $89.48 \%$ when milk fat content increased from 0.54 to $2.00 \%$, but it slightly decreased when milk fat was further increased to $3.30 \%\left(\% \mathrm{REC}_{\mathrm{FAT}}=\right.$ $87.84 \%$ ). In goats, $\% \mathrm{REC}_{\mathrm{FAT}}$ increased linearly (Supplemental Figure S1; https://doi.org/10.3168/jds.2018 -15397) across all classes of milk fat. The differences between the 2 species could be due to differences in the size of milk fat globules and the tendency of fat globules to aggregate into clusters (Guinee and McSweeney, 2006).

The higher milk fat content was also associated with higher values of recovery of milk protein, TS, energy, and water in curd (Table 3). In bovine milk, fat glob-

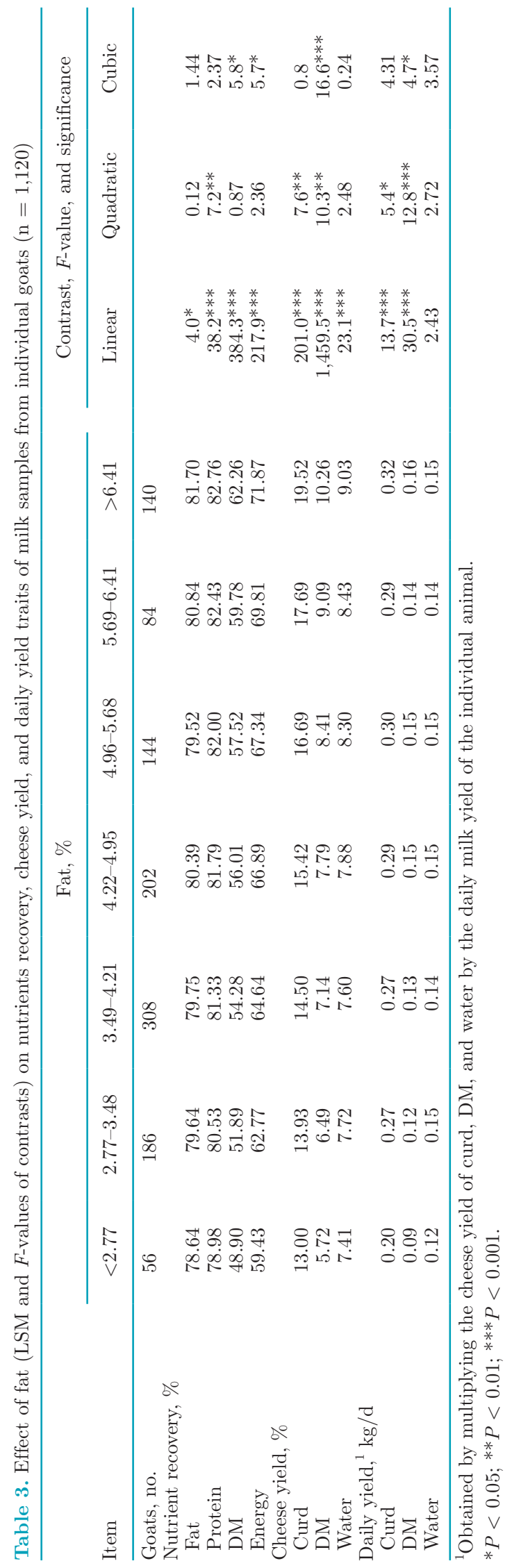

Journal of Dairy Science Vol. 102 No. 5, 2019 
ules represent a physical limit for the contraction of the para-casein network, and they therefore reduce the extent of syneresis (Guinee and McSweeney, 2006). On the contrary, in goat milk, fat does not affect the extent of syneresis (Stocco et al., 2018b). In the present study, the comparison of samples from the lowest and the highest class of milk fat (Table 3) showed an increased $\% \mathrm{CY}_{\text {WATER }}$ (from 7.41 to $9.03 \%$ ) and an almost 2-fold increase of $\% \mathrm{CY}_{\text {SOLIDS }}$ (from 5.72 to $10.26 \%$ ). Given that this effect was also found for daily yield traits, it could be speculated that the positive contribution of fat to \% CY was directly mediated by the fat content rather than by water.

The study by Fox et al. (2017), dealing with the processing of Cheddar cheese, elucidated the complex relationships among milk constituents in the bovine species. Fat, casein, and casein-to-fat ratio are the main traits affecting cheese yield, as caseins create the continuous para-casein network occluding fat and water but fat has limited ability in holding water. Hence, a high casein-to-fat ratio is associated with a higher percentage of moisture trapped in the casein network. Moisture contributes to cheese yield directly and indirectly because of dissolved solids (i.e., whey proteins and soluble milk salts).

\section{Contribution of Protein}

Milk samples from the lowest to the highest class of protein content (Table 4) showed an increased \% REC $(7.3 \%), \%$ REC $_{\text {SOLIDS }}(7.8 \%)$, and \%REC ENERGY $(5.8 \%$; data not shown in tables). The effect was also positive on all $\% \mathrm{CY}$ traits $(2.2,1.9$, and $0.9 \%$, respectively, for $\% \mathrm{CY}_{\text {CURD }}, \% \mathrm{CY}_{\text {SOLIDS }}$, and $\% \mathrm{CY}_{\text {WATER }}$; data not shown in tables). These results were expected because, similar to fat, milk protein is a major component of cheese and it is correlated with \%CY traits (Guo et al., 2004; Zeng et al., 2007).

Different from fat, the effect of milk protein content on $\% \mathrm{REC}_{\text {PROTEIN }}$ across classes of milk protein (Table 4) was not significant. It should be considered that the statistical model also included the effect of casein number, so the effect of total protein was corrected for the ratio between caseins and whey proteins, which was supposed to be one of the main factors affecting quality of milk protein.

Milk protein content significantly affected $\% \mathrm{REC}_{\mathrm{FAT}}$, $\% \mathrm{REC}_{\text {SOLIDS }}$, and \%REC $\mathrm{RNERGY}_{\text {, with a linear trend }}$ (Supplemental Figure S2; https://doi.org/10.3168/jds .2018-15397). As previously reported for the contribution of fat, the significant linear association found between protein content and $\% \mathrm{REC}_{\mathrm{FAT}}$ (Table 4) is attributable to the network of casein entrapping milk fat, which is then recovered in the curd. It worth noting

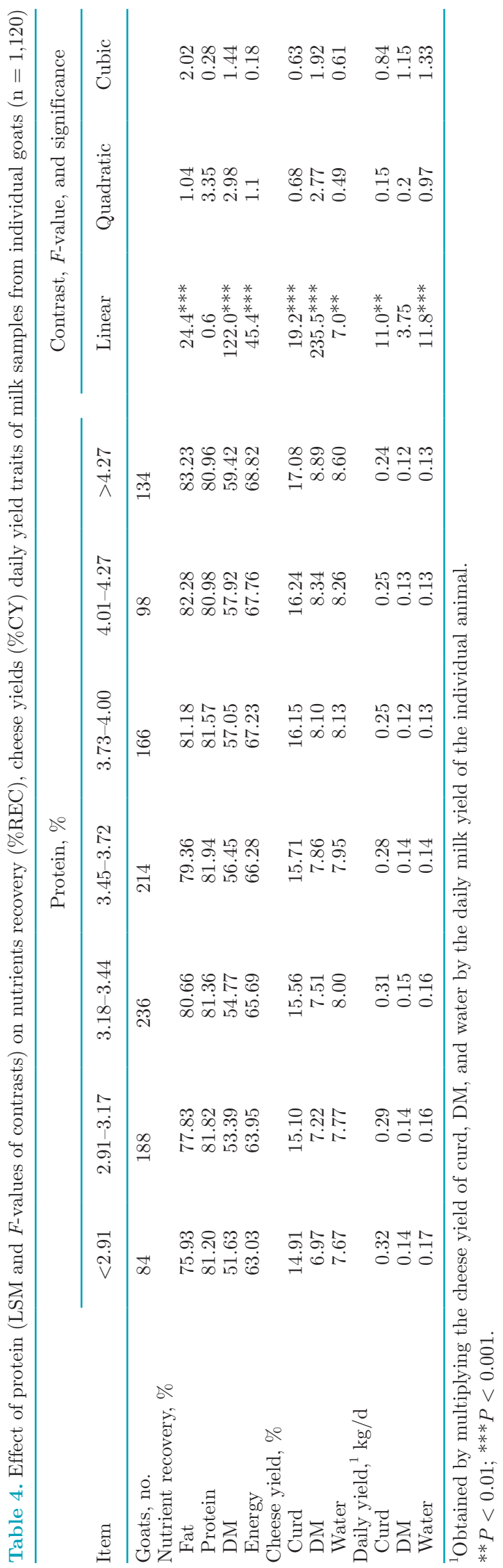


that $\% \mathrm{REC}_{\mathrm{FAT}}$ was greatly improved by increasing milk protein content $(F$-value of linear contrast at $24.4, P$ $<0.001$; Table 4) than by increasing milk fat content ( $F$-value of linear contrast at 4.0, $P<0.05$; Table 3 ). The effect of protein on $\% \mathrm{REC}_{\mathrm{FAT}}$ was expected to be favorable, especially in goats, because fat globules in goat milk are smaller than those in bovine (Michalski et al., 2003), and smaller globules appear to be better retained in thicker casein network.

Even if the higher $\% \mathrm{CY}_{\text {WATER }}$ was associated with an augmented $\% \mathrm{CY}_{\text {CURD }}$, the linear increase of $\% \mathrm{CY}_{\text {WATER }}$ could be not considered a positive finding because an excess of water in the curd generally leads to a worsening of cheese quality during ripening, with a final depreciation of the product (Martin et al., 1997). Samples with high contents of both fat and protein showed a concurrent increase of \% $\mathrm{CY}_{\text {WATER }}$ and, in particular, $\% \mathrm{CY}_{\text {SOLIDS }}$ (Tables 3 and 4); however, the composition of curd changed with different values of moisture percentage for increasing classes of fat and protein. Indeed, if the ratio between $\% \mathrm{CY}_{\text {WATER }}$ and $\% \mathrm{CY}_{\text {SOLIDS }}$ was calculated, the value was almost steady from the lowest to the highest class of milk protein content (51.4-50.4, data not shown in tables), whereas it decreased from 57 for fat content $<2.77 \%$ to 46.3 for fat content $>6.41 \%$ (data not shown in tables).

\section{Contribution of Casein Number}

Casein number, calculated as the proportion of caseins to proteins, was expected to be an important predictor of $\% \mathrm{REC}_{\text {PROTEIN }}$ because the major part of caseins is normally entrapped in the curd while whey proteins pass that barrier. In the present study, $\% \mathrm{REC}_{\text {PROTEIN }}$ was not affected by casein number, with a approximately constant value across the different classes of casein number (Table 5). The difference between the values of $\% \mathrm{REC}_{\text {PROTEIN }}$ and casein number (data not shown in tables) was positive for milk samples from the lowest class of casein number, 7.97, and slightly negative, -1.13 , in those from the highest class. This would mean that part of whey proteins were entrapped in the curd in the first case and that some caseins were lost in the second case, as also suggested by the decrease of $\% \mathrm{REC}_{\text {SOLIDS }}$ in milk samples with greater casein numbers (Table 5). The absence of an effect of casein number on $\% \mathrm{REC}_{\text {PROTEIN }}$ confirmed the nonsignificant effect observed for protein content on the same trait (Table 4). In accordance with the present study, Zeng et al. (2007) report that a predictive formula including only milk protein is less effective $(r=0.73)$ than one including only fat $(\mathrm{r}=0.81)$; if protein and fat are included together in the formula, no improvement is recorded $(r=0.81)$ and the regression coefficient for fat (5.72) is much larger than that for protein (0.29). Moreover, casein is characterized by a negative regression coefficient $(-0.65)$, and the addition of casein does not further improve the accuracy of the predictive formula $(\mathrm{r}=0.81)$ of semihard and hard goat cheeses (Zeng et al., 2007).

Casein number also influenced $\% \mathrm{REC}_{\mathrm{FAT}}$ and

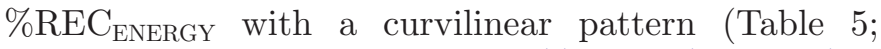
Supplemental Figure S3; https://doi.org/10.3168/jds .2018-15397).

With regard to coagulation properties of goat milk, Stocco et al. (2018b) reported that high values of casein number $(>82 \%)$ were associated with a general improvement of coagulation ability of goat milk, but no information is available about the effect of casein number on milk nutrient recovery in goat cheese. Some studies on bovine milk have clarified that, other than the ratio between caseins and whey proteins, the proportions among individual caseins and whey protein fractions also significantly affect both milk coagulation properties (Amalfitano et al., 2019) and cheesemaking efficiency traits (Cipolat-Gotet et al., 2018). Large breed differences in the proportions among individual protein fractions in goat milk have been demonstrated (Moatsou et al., 2008; Thomann et al., 2008), but their effects were only studied in relation to milk coagulation properties (Clark and Sherbon, 2000) and cheese yield (Damián et al., 2008). No information is available on the effects of breed on the recovery of milk nutrients in cheese, and that topic deserves further research for improving the knowledge on the complex relationships between goat milk composition and cheesemaking process.

\section{CONCLUSIONS}

The current study allowed us to quantify the effect of the major milk nutrients on nutrient recovery, cheese yield, and daily yield traits of goat milk. In particular, the increase of milk fat improved cheese yield, not only because fat is one of the most important components of cheese, but also because it positively affected its recovery rate and of protein, TS, and energy. Fat also caused a higher retention of water and solids in cheese. Milk protein improved the recovery of nutrients in the curd, particularly fat recovery, with a significant positive contribution to individual \% CY and daily yield traits. Contrary to what we expected, casein number slightly affected the recovery rate of protein, whereas it affected to a greater degree the recovery of fat. In conclusion, the present study allowed for a better understanding of the role of fat, protein, and casein number of milk on the productivity and efficiency of dairy goats, but a better definition of cheesemaking efficiency could be 
achieved in studies by including the effects of individual milk protein fractions and their genetic variants.

\section{ACKNOWLEDGMENTS}

This research was supported by the Regional Government of Sardinia (Legge Regionale 7/2007; CUP J72I15000030007). We thank the farmers for giving access to their flocks; the A.I.P.A./A.P.A.s (Provincial Farmers Associations) of Cagliari, Nuoro, Sassari, and Oristano (Italy) and the firms Sepi Formaggi (Marrubiu, Italy) and L'Armentizia Moderna (Guspini, Italy) for their support in sample collection; A.R.A. Sardegna (Regional Farmers Association of Sardinia, Cagliari, Italy) for support in chemical milk analysis.

\section{REFERENCES}

Amalfitano, N., C. Cipolat-Gotet, A. Cecchinato, M. Malacarne, A. Summer, and G. Bittante. 2019. Milk protein fractions heavily affect the pattern of coagulation, curd firming and syneresis. J. Dairy Sci. 102:2903-2918.

Banks, J. M., and A. Y. Tamime. 1987. Seasonal trends in the recovery of milk fat and casein in cheese manufacture. Int. J. Dairy Technol. 40:64-66.

Bittante, G., M. Penasa, and A. Cecchinato. 2012. Invited review: Genetics and modeling of milk coagulation properties. J. Dairy Sci. 95:6843-6870.

Boyazoglu, J., and P. Morand-Fehr. 2001. Mediterranean dairy sheep and goat products and their quality. A critical review. Small Rumin. Res. 40:1-11.

Cipolat-Gotet, C., A. Cecchinato, and G. Bittante. 2016. Phenotypic analysis of cheese yields and nutrient recoveries in the curd of buffalo milk, as measured with an individual model cheese-manufacturing process. J. Dairy Sci. 99:1065-1082.

Cipolat-Gotet, C., A. Cecchinato, M. Malacarne, G. Bittante, and A. Summer. 2018. Variations in milk protein fractions affect the efficiency of the cheese-making process. J. Dairy Sci. 101:8788-8804

Clark, S., and J. W. Sherbon. 2000. Alphas1-casein, milk composition and coagulation properties of goat milk. Small Rumin. Res. $38: 123-134$.

Damián, J. P., I. Sacchi, S. Reginensi, D. De Lima, and J. Bermúdez. 2008. Cheese yield, casein fractions and major components of milk of Saanen and Anglo-Nubian dairy goats. Arq. Bras. Med. Vet. Zootec. 60:1564-1569.

Emmons, D. B., and H. W. Modler. 2010. Invited review: A commentary on predictive cheese yield formulas. J. Dairy Sci. 93:55175537.

Fenelon, M. A., and T. P. Guinee. 1999. The effect of milk fat on Cheddar cheese yield and its prediction, using modifications of the van Slyke cheese yield formula. J. Dairy Sci. 82:1-13.

Fox, P. F., T. P. Guinee, T. M. Cogan, and P. L. H. McSweeney. 2017. Fundamentals of Cheese Science. 2nd ed. Springer, New York, NY.

Goetsch, A. L., S. S. Zeng, and T. A. Gipson. 2011. Factors affecting goat milk production and quality. Small Rumin. Res. 101:55-63.

Guinee, T. P., and P. L. H. McSweeney. 2006. Significance of milk fat in cheese. Pages 377-440 in Advanced Dairy Chemistry, Lipids. Vol. 2. 3rd ed. Fox, P. F., and P. L. H. McSweeney, ed. Springer, New York, NY.

Guo, M., Y. W. Park, P. H. Dixon, J. A. Gilmore, and P. S. Kindstedt. 2004. Relationship between the yield of cheese (Chevre) and chemical composition of goat milk. Small Rumin. Res. 52:103-107.

ISO-IDF. 2013. Milk and liquid milk products. Determination of fat, protein, lactose, $\mathrm{pH}$, and $\mathrm{NaCl}$ content. International Standard ISO 9622 and IDF 141:2013. International Organization for Stan- 
dardization, Geneva, Switzerland, and International Dairy Federation, Brussels, Belgium.

Kalantzopoulos, G. C. 1993. Cheeses from ewes' and goats' milk. Pages 533-540 in Cheese: Chemistry, Physics and Microbiology: Major Cheese Groups, vol. 2, 2nd ed. P. F. Fox, ed. Chapman \& Hall, New York, Ny.

Lôbo, A. M. B. O., R. N. B. Lôbo, O. Faco, V. Souza, A. A. C. Alves, A. C. Costa, and M. A. M. Albuquerque. 2017. Characterization of milk production and composition of four exotic goat breeds in Brazil. Small Rumin. Res. 153:9-16.

Martin, B., J.-F. Chamba, J.-B. Coulon, and E. Perreard. 1997. Effect of milk chemical composition and clotting characteristics on chemical and sensory properties of Reblochon de Savoie cheese. J. Dairy Res. 64:157-162.

Michalski, M.-C., J.-Y. Gassi, M.-H. Famelart, N. Leconte, B. Camier, F. Michel, and V. Briard. 2003. The size of native milk fat globules affects physico-chemical and sensory properties of Camembert cheese. Lait 83:131-143.

Moatsou, G., E. Moschopoulou, D. Mollé, V. Gagnaire, I. Kandarakis, and J. Léonil. 2008. Comparative study of the protein fraction of goat milk from the Indigenous Greek breed and from international breeds. Food Chem. 106:509-520.

NRC. 2001. Nutrient Requirements of Dairy Cattle. 7th rev. ed. Natl. Acad. Press, Washington, DC.

Othmane, M. H., J. A. Carriedo, L. F. de la Fuente Crespo, and F. San Primitivo. 2002. An individual laboratory cheese-making method for selection in dairy ewes. Small Rumin. Res. 45:67-73.

Pazzola, M., G. Stocco, M. L. Dettori, C. Cipolat-Gotet, G. Bittante, and G. M. Vacca. 2018. Modeling of coagulation, curd firming, and syneresis of goat milk. J. Dairy Sci. 101:7027-7039.

Soryal, K., F. A. Beyene, S. Zeng, B. Bah, and K. Tesfai. 2005. Effect of goat breed and milk composition on yield, sensory quality, fatty acid concentration of soft cheese during lactation. Small Rumin. Res. 58:275-281.

Stocco, G., C. Cipolat-Gotet, V. Gasparotto, A. Cecchinato, and G. Bittante. 2018a. Breed of cow and herd productivity affect milk nutrient recovery in curd, and cheese yield, efficiency and daily production. Animal 12:434-444.

Stocco, G., M. Pazzola, M. L. Dettori, P. Paschino, G. Bittante, and G. M. Vacca. 2018b. Effect of composition on coagulation, curdfirming and syneresis of goat milk. J. Dairy Sci. 101:9693-9702.

Sung, Y. Y., T. I. Wu, and P. H. Wang. 1999. Evaluation of milk quality of Alpine, Nubian, Saanen and Toggenburg breeds in Taiwan. Small Rumin. Res. 33:17-23.

Thomann, S., A. Brechenmacher, and J. Hinrichs. 2008. Strategy to evaluate cheesemaking properties of milk from different goat breeds. Small Rumin. Res. 74:172-178.

Vacca, G. M., G. Stocco, M. L. Dettori, E. Pira, G. Bittante, and M. Pazzola. 2018b. Milk yield, quality and coagulation properties of six breeds of goats: Environmental and individual variability. J. Dairy Sci. 101:7236-7247.

Vacca, G. M., G. Stocco, M. L. Dettori, A. Summer, C. Cipolat-Gotet, G. Bittante, and M. Pazzola. 2018a. Cheese yield, cheese-making efficiency, and daily production of six breeds of goats. J. Dairy Sci. 101:7817-7832.

Verdier-Metz, I., J.-B. Coulon, and P. Pradel. 2001. Relationship between milk fat and protein contents and cheese yield. Anim. Res. $50: 365-371$.

Verdier-Metz, I., J.-B. Coulon, P. Pradel, and J. L. Berdagué. 1995. Effect of forage type and cow breed on the characteristics of matured Saint-Nectaire cheeses. Lait 75:523-533.

Zeng, S. S., K. Soryal, B. Fekadu, B. Bah, and T. Popham. 2007. Predictive formulae for goat cheese yield based on milk composition. Small Rumin. Res. 69:180-186. 